in incidence in Britain (in the manner demonstrated in diverticulosis), then remain stationary or even fall (as occurred in diabetes $^{2}$ ) during rationing? A full list of these peculiar diseases, which included diverticulosis, derived from the observations of workers in Africa, was suggested some 12 years ago. ${ }^{3}$ To this list varicose veins and osteoarthrosis should be added. Even blood pressure may remain stationary throughout life ${ }^{4}$ and serum cholesterol may fall. ${ }^{5}$

From 1955 and now spreading to some 16 of the most developed countries ${ }^{6}$ there has been a definite but slight decreased expectation of life in adults, to which atheroma makes the major contribution. In Britain al cohorts aged 15-75 had a decreased expectation of life in 1969, only those over 75 had increased expectation. ${ }^{7}$ I suggest that the latter group were born largely before major changes of feeding infants and adults occurred towards the end of the last century.

The pioneer studies of Cleave $^{8}$ have suggested that we should look on chronic diseases of unknown aetiology in terms of poor adaptation to new environmental factors-new in the time-scale of evolution Caries-a failure to starch and sugar, diverticulosis-a failure to low fibre. To these I now add kwashiorkor-a failure of the weanling to adapt to protein-poor diets, and lung cancer $-a$ failure to adapt to cigarette smoke. Weaklings go to the wall; the species survives.

This brilliant new perspective opens up fundamental insights. We must consider how our children are adapting to evolutionary recent changes in their upbringing: seldom

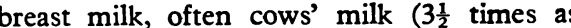
much protein) at all ages; optimal diets containing much sugar and refined cereals. Fed thus they mature rapidly; the menarche has fallen 5-6 years in little over a century. Western-fed children and adults have milieu intérieure statistically different in many respects from that of those reared in the ancient manner. ${ }^{3}$

Might not the traditional African blood cholesterol at 40 years $147 \mathrm{mg} / 100 \mathrm{ml}$ and fasting blood sugar $106 \mathrm{mg} / 100 \mathrm{ml}$ be the human normal, and explain partially the low incidence of atheroma and diabetes, until nowadays diets and disease incidence change into the Western pattern?-I am, etc.,

\section{Hugh Trowel}

\section{Fordingbridge,}

Hants

1 Cohen, A. M., Kaufmann, N. A., Poznanski, R. Blondheim, S. H., and Stein, Y., British Medical
fournal, 1966, 1, 339 . Sroceedings of the Royal

Society Medicine, 1949, 42, 323

Trowell $\mathrm{H}$ C. Non-Infective Disease in Africa. pp. 465 and 467 . London, Arnold, 1960.

Pickering, G., High Blood Pressure, 2nd edn. p. 226. London, Churchill, 1968.

Shaper. A. G., and Jones, K. W. Lancet, 1959, 2,534 .

Medical News Tribune, 1970, 2, No. 46

The Times. 20 May 1971, p. from The Registrar's General Statistical Reviezv of England and Wals H.M.S.O., 1971

Cleave, T.' L., Campbell, G. D., and Painter, Saccharine Disease, 2nd edn. Wright, Bristol, 1969.

\section{Humidity in Hospitals}

SIR,-This letter is stimulated by the article on mucolytic agents (5 June, p. 581) which mentions the value of steam inhalations. I wonder whether medical advisory committees to hospitals are aware of the importance to chest patients of maintaining an adequate degree of relative humidity in the air of wards?

My limited experience of hospitals is that in winter the air becomes much too dry, so making the sputum of patients suffering from chest infections much more viscid. Not so many years ago, in the old Nightingaletype of wards, an electric sterilizer kept steaming away, so keeping the air moist. Nowadays, even the windows are kept shut, to save on the heating bills.

My own experience of a new centrallyheated house is that for two winters running I suffered from acute sinusitis, until I discovered the cure was adequate humidification of the air. I found this out only after buying a sensitive and accurate hygrometer, which showed that last winter the percentage relative humidity inside the house was only $30 \%$, although in the outside air it quickly registered $65 \%$. The optimum relative humidity at $70^{\circ} \mathrm{F}\left(21^{\circ} \mathrm{C}\right)$ is about $50^{\prime}$. One year previously I had bought an inexpensive hygrometer which registered much the same winter and summer, indoors and outdoors, so it is false economy to buy a cheap instrument.-I am, etc.

Municipal Offices, Boroughs of Calne, Chippenham, and Malmesbury,
Wilts

\section{Sniffing Syndrome}

SIR,-Your leading article on the "Sniffing Syndrome" (24 April, p. 183) issue draws attention to an important social and medical problem which, fortunately for the majority of your readers, does not appear to be as widespread in Europe as in the United States.

I would, however, take issue with your apparently uncritical acceptance of the conclusion of the report by Taylor and Harris and draw your attention to two publications from this laboratory ${ }^{2} 3$ that show firstly, that the results obtained by Taylor and Harris can be explained on the grounds of anoxia alone and, secondly, that the ability to sensitize the heart to sympathomimetic agents is a property shared by many hydrocarbons and halocarbons. As with many questions dealing with toxicity, it is the dose necessary to produce a particular effect that is important and in this regard there is no evidence that cardiac sensitization occurs at inspired air concentrations of the various agents that are associated with normal use conditions. The teenagers that have died have been inhaling exceedingly high concentrations of the compounds under conditions of gross abuse of the intended use of the product. The asthma inhalers present a different problem since there appears to be no evidence from countries other than the U.K. for an increase in asthma deaths, and I believe that this increase has now ceased and that asthma deaths have declined to the levels prevailing prior to the introduction of the pressurized aerosol inhalers containing fluorocarbons. The fact that under conditions of gross overdosage Professor C. T. Dollery ${ }^{4}$ was able to detect fluorocarbon levels in the blood is not in itself surprising or an indictment of the safety of the propellants. What is needed is quantitative information on the levels of halocarbon in the blood that are associated with a serious risk of cardiac arrhythmias.
This information is now being gathered by several organizations. Since it has been shown by Reinhardt et al. ${ }^{2}$ that the fluorocarbon propellants vary in their ability to cause sensitization of the heart to epinephrine, it may be that for certain purposes, such as the medicated aerosols that are intended to be inhaled, the substitution of propellants having a very small potential for causing the sensitization phenomenon would further enhance the safety factor in this type of application-I am, etc.,

\section{G. J. STOPpS}

Haskell Laboratory for Toxicology and

Industrial Medicine, du Pont de Nemours and Co. Wilmington, Del., U.S.A

Taylor, G. J., and Harris, W. S., Fournal of the American Medical Association, 1970, 214, 81. inhardt, C. F., Azar, A., Mayfield, M. E., Smith P. E., jun., and Mullin, L.S

Azar, A., Zapp, J. A., Reinhardt, C. F., and Stopps, G. J., fournal of the American Medical Association, 1971, 215, 1501 .

Wollery, C. T., Draffan, G. M., Davies, D. S.,
ill iams, F., and Connolly, M. E., Lancet, 1970, 2,1164 .

SIR,-Your recent leading article on the "Sniffing Syndrome" (24 April, p. 183) has prompted me to offer a brief account of experiments we have recently carried out to assess the potential danger of aerosol propellants to asthmatic patients. The starting points of our work were the report by Taylor and Harris, ${ }^{1}$ which seemed to show that propellants like Freons 11 and 12 were highly toxic to heart muscle in anaesthetized, hypoxic mice, and the report by Reinhardt et al.,2 which showed that aerosol propellants, like many other organic solvents, could sensitize the heart of conscious dogs to large intravenous challenges with adrenaline.

Our first experiments were obviously directed to checking the surprising results reported by Taylor and Harris. We quickly found that this work could not be repeated by us; this has also been the experience of Azar et $a .^{3}$ and of Silverglade. ${ }^{4}$ The apparent cardiotoxic effect found by Taylor and Harris depended on their finding that control animals, which received no propellants, could be totally deprived of air for three to four minutes with only minor changes in cardiac performance. There can be few, if any, mammalian species for which this is true. Our mice responded to asphyxiation with brief tachycardia which was followed by bradycardia and then by major arrhythmias as the degree of hypoxia increased. The hearts of animals which received propellant gases or nitrogen before being asphyxiated behaved in essentially the same way but, not surprisingly, the symptoms occurred a little earlier because most of the oxygen in their lungs had been removed by the pretreatment.

The work of Reinhardt et al. is different and gives rise to these questions: What concentrations of aerosol propellants are necessary to sensitize heart muscle to adrenaline? Do these concentrations adversely affect cardiac performance in hypoxic, anxious individuals? Can such concentrations be achieved in the blood of asthmatic patients who abuse inhalers?

We have found that blood concentrations of about $20-25 \mu \mathrm{g} / \mathrm{ml}$ of Freon 11 and about twice this amount of Freon 12 are the limiting levels for cardiac sensitization to adrenaline challenge in conscious dogs. These or 